\title{
Review
}

\section{Gene-Modified Dendritic Cells for Use in Tumor Vaccines}

\author{
CHRISTOPHER J. KIRK ${ }^{1,2}$ and JAMES J. MULÉ ${ }^{1-3}$
}

\begin{abstract}
Dendritic cells (DCs) are potent antigen-presenting cells capable of priming activation of naive $T$ cells. Because of their immunostimulatory capacity, immunization with DCs presenting tumor antigens has been proposed as a treatment regimen for cancer. The results from translational research studies and early clinical trials point to the need for improvement of DC-based tumor vaccines before they become a more broadly applicable treatment modality. In this regard, studies suggest that genetic modification of DCs to express tumor antigens and/or immunomodulatory proteins may improve their capacity to promote an antitumor response. Because the DC phenotype is relatively unstable, nonperturbing methods of gene transfer must be employed that do not compromise viability or immunostimulatory capacity. DCs expressing transgenes encoding tumor antigens have been shown to be more potent primers of antitumor immunity both in vitro and in animal models of disease; in some measures of immune priming, gene-modified DCs exceeded their soluble antigen-puls ed counterparts. Cytokine gene modification of DCs has improved their capacity to prime tumor antigenspecific $T$ cell responses and promote antitumor immunity in vivo. Here, we review the current status of genemodified DCs in both human and murine studies. Although successful results have been obtained to date in experimental systems, we discuss potential problems that have already arisen and may yet be encountered before gene-modified DCs are more widely applicable for use in human clinical trials.
\end{abstract}

\section{OVERVIEW SUMMARY}

This review discusses the potential benefits and limitations of genetically modified dendritic cells (DCs) for use in therapeutic antitumor vaccines. We discuss the various systems employed for gene transfer to DCs, including the growing consensus that viral vectors represent the most efficient means of transduction. We also describe data supporting the use of DCs modified to express genes encoding tumor antigens and immunomodulatory proteins, such as cytokines, to promote antitumor immunity. Successful preclinical results are described, in which genetically modified DCs are used in in vitro immunologic studies with human cells in vitro as well as animal tumor models in vivo. We point out the benefits and disadvantages of using genemodified DCs and express our viewpoint on what types of gene-modified DCs may be considered candidates likely to reach the clinic.

\section{INTRODUCTION}

\footnotetext{
Q ince their Discovery more than 25 years ago, dendritic cells (DCs) have emerged as the most potent member of the class of antigen-presenting cells (APCs) (Banchereau and Steinman, 1998). Because of their potent capacity to stimulate T lymphocytes, particularly naive $\mathrm{T}$ cells, DCs have been proposed as the basis for vaccines designed for the treatment of cancer (Cohen et al., 1994; Schuler and Steinman, 1997). Coupled with our understanding that tumors express antigens (TAA, tumorassociated antigen) capable of being recognized by the immune system, DC-based tumor vaccines have been translated from the laboratory to the clinic (Timmerman and Levy, 1999). The results from early phase I clinical trials support the idea that DCs presenting TAA can initiate an antitum or immune response in certain patients and, in some cases, can lead to partial or complete regression of tumors (Hsu et al., 1996; Nestle et al., 1998). Although these early results are encouraging, they also
}

${ }^{1}$ Department of Surgery, ${ }^{2}$ Tumor Immunology Program of the Comprehensive Cancer Center, and ${ }^{3}$ Department of Internal Medicine, University of Michigan Medical Center, Ann Arbor, MI 48109. 
point to the exigency for modification of DC-based vaccines before they become a commonly used modality for the treatment of cancer. Gene therapy in the setting of DC-based vaccines represents one such modification. The purpose of this review is to bring together data on gene techniques and translational research using gene-modified DCs. By drawing parallels from animal models and in vitro assays utilizing human cells, we hope to highlight the promise entailed in creating the next generation of vaccines based on genemodified DCs.

\section{DC generation and morphology}

Because DCs can be derived from multiple cell types using a number of different tissue culture conditions, a brief primer on DC generation and phenotype is necessary before we can begin to address issues of gene transfer. DCs are distinguished by their dendritic, veiled morphology (Fig. 1) and high expression levels of both MHC class I and class II as well as costimulatory and adhesion molecules involved in $\mathrm{T}$ cell activation such as CD80/CD86 and ICAM-1 (Hart, 1997; B anchereau and Steinman, 1998). DCs reside in the spleen, lymph nodes, and circulation but can arise from cells such as epidermal Langerhans cells or monocytes, which react to stimuli such as inflammatory cytokines.

An important step in the application of DCs in therapeutic settings was the ability to obtain them in large numbers in highly purified form from donors. In both rodents and humans, DCs can be generated from bone marrow or peripheral blood cells; in the case of peripheral blood both circulating $\mathrm{CD} 34^{+}$ hematopoietic progenitor cells and $\mathrm{CD} 14^{+}$adherent monocytes were found to give rise to DCs under defined tissue culture conditions. On culture in the presence of granulocyte-ma crophage colony-stimulating factor (GM-CSF) and interleukin 4 (IL-4), the resulting cells display the veiled morphology characteristic of DCs and express T cell stimulatory molecules such as MHC I/II, CD80/86, and ICAM-1 (Bender et al., 1996; Romani et al., 1996; Talmor et al., 1998). In humans, these cells represent "immature DCs," defined in part by their high antigen uptake. Further culture of these cells in monocyte conditioned medium

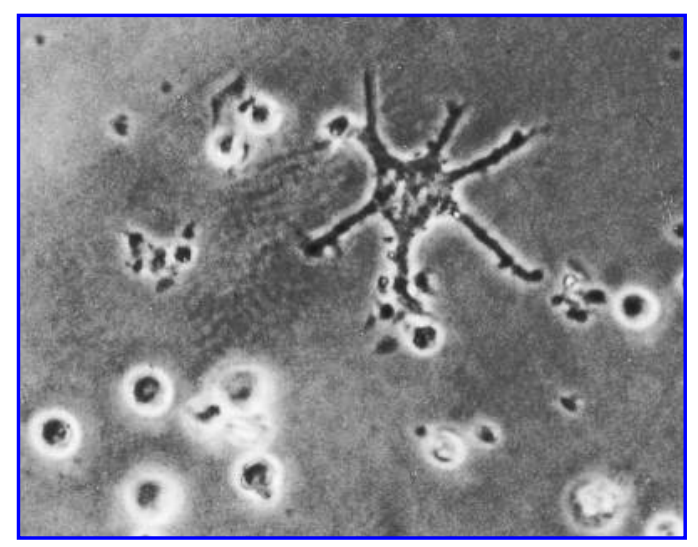

FIG. 1. Photomicrograph of a murine dendritic cell. Typical morphology shows a stellate appearance with multiple cell processes. The DC was isolated from spleen as described in Fields et al. (1998).
(MCM) or with the addition of tumor necrosis factor $\alpha$ (TNF- $\alpha$ ), lipopolysaccharid e, type I interferons (IFNs), or IL$1 \beta$ can increase the expression of $\mathrm{T}$ cell stimulatory receptors and induce expression of DC maturation markers such as CD83 (Bender et al., 1996; Luft et al., 1998). These "mature DCs" are more potent $\mathrm{T}$ cell stimulators than immature DCs but have reduced phagocytic and endocytic activities (Banchereau and Steinman, 1998). Mature DCs are thought to be better for use in immunization regimens than their immature counterparts because of their increased immunostimulatory capacity, stability of their phenotype, and increased trafficking to lymphoid organs. In the mouse the distinction between immature and mature DCs is not clear-cut due, in part, to lack of a selectable marker for maturation. However, murine bone marrow-derived DCs (BMDCs) cultured in GM-CSF plus IL-4 are functionally more mature (as measured by phagocytic/endocytic activities and T-cell stimulatory capacity) than DCs derived from GMCSF cultures (Talmor et al., 1998; Labeur et al., 1999). The addition of CD40L or TRANCE, both ligands for TNF receptor family members, has also been shown to promote the maturation and survival of DCs (Wong et al., 1997; Kuniyoshi et al., 1999). Taken together, it appears that multiple modes of DC maturation are capable of resulting in a cell with high immunostimulatory capacity. Whether these different sources of DC progenitors and different protocols for DC generation result in similarly effective antigen-presenting cells is a matter still open to debate but should be kept in mind by the reader of both clinical and translational research reports.

\section{GENETIC MODIFICATION OF DENDRITIC CELLS}

Broadly defined, the target genes transferred into DCs fall into two categories: TAA and immunomodulato ry proteins such as cytokines. In the case of DCs expressing TAA, gene constructs encoding whole proteins and cytotoxic $\mathrm{T}$ lymphocyte (CTL)-specific epitopes have been utilized. There are a number of potential advantages to using TAA gene-modified DCs. DCs expressing TAA via a transgene should, in theory, present antigen for a longer period than peptide or tumor lysate-pulsed DCs, in which the duration of expression is restricted by the half-life of the peptide-MHC complex created during antigen pulsing. Plasmid DNA is relatively stable and easy to generate, making it a more suitable source of antigen than whole tumor RNA and eliminating the possible transformation of DCs by oncogenes or tumor suppressor genes encoded in tumor DNA. However, TAA gene-transfected DCs present only the antigen encoded by the transgene, resulting in an antigenic restriction not present when tumor lysate or RNA/DNA is used as the antigen source. Because DCs are potent APCs, use of viral gene vectors could result in priming of antiviral immunity, particularly CTLs, resulting in elimination of transfected DCs during subsequent rounds of immunization. Furthermore, the relative instability of the DC phenotype necessitates a method of transfection that does not compromise viability or negatively affect DC functions (Fields et al., 1998). The challenge to the broader use of gene-modified DCs in vaccine applications then is twofold: determine the most efficient means of transfecting DCs 
and the optimal target genes to be transfected. In this regard, DCs transfected with genes encoding cytokines or T cell costimulatory molecules represent APCs that are potentially more immunostimulatory or longer lived than unmodified DCs.

\section{Efficient gene transfer into DCs via viral vectors}

Published reports of gene-modified DCs have used a variety of gene transfer vehicles including cationic lipids, viral vectors, and plasmid-coated gold particles (Table 1). Gene transfer efficiencies, when reported, ranged from 5\% efficiency to greater than $95 \%$ transgene-expressing cells. The variation in gene transfer efficiencies may be due, in part, to the transfection vector system employed but may also be due to modifications in gene transfer protocols. Several laboratories have attempted to determine which gene transfer system(s) are optimal for transfecting DCs efficiently. The growing consensus is that viral vectors represent a more efficient and productive means compared with physical or chemical methods. While the majority of published reports detailing virus-mediated transduction efficiency and its effect on DC phenotype have utilized adenovirus, DCs or their progenitors have been transduced with similar efficiencies in studies using retrovirus (Aicher et al., 1997), poxvirus (Brown et al., 1999), and herpesvirus (Coffin et al., 1998).

In direct comparisons of adenoviral vectors with physical methods of transfection such as liposomes, electroporation and $\mathrm{CaPO}_{4}$, viral vectors have resulted in consistently higher levels of gene transfer efficiency and expression and transfection efficiencies (90-100 versus 5-10\%) (Arthur et al., 1997; Dietz and Vuk-Pavlovic, 1998; Zhong et al., 1999). In fact, most physical methods of transfection were toxic to DCs, resulting in loss of phenotype and substantial cell death (Arthur et al.,
1997). Even under optimal conditions when electroporation resulted in $15 \%$ transfection efficiency, viability of the DC was less than 60\% (Van Tendeloo et al., 1998), and transfection via electroporation occurred in $\mathrm{CD}_{3} 4^{+}$HSC-derived but not in monocyte-derive d DCs. However, it should be noted that substantial protein production after gene gun transfection has been achieved, although no determination of transfection efficiency was determined (Tuting et al., 1998). Adenovirus titers of up to 1000-10,000 multiplicities of infection (MOIs) could be well tolerated by DCs as opposed to the M202 and M207 human melanom a cell lines, which demonstrated 40-100\% cell death at the same titers (Arthur et al., 1997). Generally, no alterations in DC phenotype after adenoviral infection have been noted (Arthur et al., 1997; Zhong et al., 1999), although there are some reports of increases in $\mathrm{T}$ cell stimulatory molecules, such as MHC class I, CD80, and CD86, suggesting that adenovirus may initiate DC maturation (Kaplan et al., 1999; Rea et al., 1999). Transgene expression in adenovirus-infecte d human DCs could persist for greater than 1 week (Arthur et al., 1997) as opposed to gene gun-mediated transfection, which resulted in only transient expression lasting less than $72 \mathrm{hr}$ (Tuting et al., 1997). When transgene expression from viral vectors was lost rapidly, addition of DC survival factors such as TRANCE could prolong reporter gene expression (although it is not known whether this effect is due to maintenance of the transgene or prolonged survival of the DCs) (Zhong et al., 1999). Adenovirus-tran sfected DCs were either as effective (Arthur $e t$ al., 1997; Zhong et al., 1999) stimulators of the mixed lymphocyte reaction (MLR) or more effective (Kaplan et al., 1999; Rea et al., 1999) than uninfected control DCs; increased stimulatory capacity accompanied increased expression of $\mathrm{T}$ cell stimulatory molecules. It appears that adenovirus has been equally capable of mediating gene transfer into human or mouse

Table 1. Gene Transfer Techniques Employed in Dendritic Cell Modification

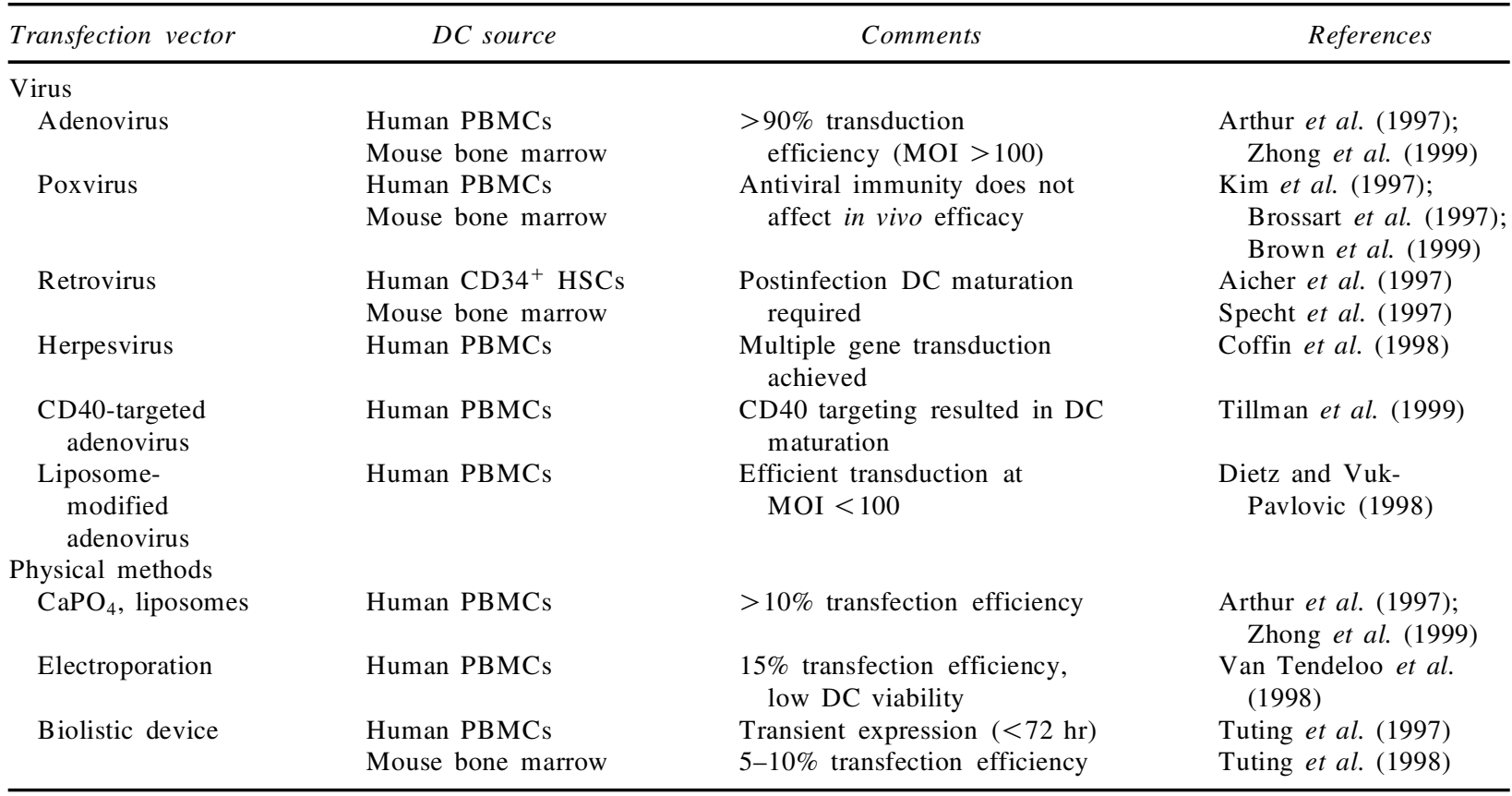

Abbreviations: PBMCs, Peripheral blood mononuclear cells; HSCs, hematopoietic stem cells; DC, dendritic cells. 
DCs (or DC lines), although no comparative studies have yet been reported (Arthur et al., 1997; Brossart et al., 1997; Ribas et al., 1997; Dietz and Vuk-Pavlovic, 1998; Sonderbye et al., 1998; Kaplan et al., 1999; Zhong et al., 1999).

The requirement for high viral titers $(\mathrm{MOI}>100)$ to achieve efficient gene transfer suggests that DCs lack the adenovirus attachment factor Coxsackie-adenovirus receptor (CAR) or the $\alpha_{\mathrm{v}}$ integrins, $\alpha_{\mathrm{v}} \beta_{3}$ or $\alpha_{\mathrm{v}} \beta_{5}$, used by the virus for fusion with its target cell (Wickham et al., 1993; Bergelson et al., 1997, 1998). Indeed, monocyte-derive d DCs cultured in GM-CSF and IL-4 are deficient in CAR but do express the $\alpha_{\mathrm{v}}$ integrin (Rea et al., 1999; Tillman et al., 1999). Instead, DCs may incorporate virus through phagocytic activity. This is consistent with the observation that gene transfer efficiency and expression levels (as measured by green fluorescent protein [GFP] fluorescence) were greater in immature DCs than in DCs induced to mature by lipopolysaccharid e (LPS) or MCM (Zhong et al., 1999). This had led some investigators to use adenovirus to enhance uptake of conjugated DNA particles or to augment adenovirus infection with antibodies or liposomes. Successful gene transfer to both mouse and human DCs has resulted using adenovirus to enhance the uptake of DNA bound to chemical linkers such as poly-L-lysine (Mulders et al., 1998), modified receptor proteins such as transferrin (Curiel-Lew androwski et al., 1999) and modified chemical linkers targeted to DC receptors such as mannosylated polyethylenimine (Diebold et al., 1999a,b). These systems, which used the virus to aid in DNA/conjugate uptake, were purported to be less toxic than using high-titer adenovirus and would result in a reduced induction of antiadenovirus immunity. Other investigators have attempted to modify adenoviral delivery to DCs by additional strategies. In this regard, adenovirus targeted to CD40 or $\beta_{1}$ integrins on human DCs by a bispecific antibody led to increased reporter gene (luciferase) activity compared with adenovirus alone, even at relatively low MOI (<100) (Tillman et al., 1999). Besides improving gene transfer efficiency, addition of CD40 antibody with the adenovirus had the additional benefit of delivering a possible DC maturation signal; both IL-12 production and allo-MLR stimulation were increased in CD40-targeted adenovirus DC preparations (Tillman et al., 1999). Improved gene transfer efficiency was also seen when adenovirus were admixed with liposomes (Dietz and Vuk-Pavlovic, 1998; Tillman et al., 1999). It is not entirely clear why Tillman et al. (1999) and Dietz and VukPavlovic (1998) reported low transduction efficiencies with unmodified adenovirus whereas Zhong et al. (1999) and Arthur et al. (1997), among others, reported productive efficiencies approaching 95-100\% of human DCs. Concerns over initiation of antiadenovirus immunity were generally not supported by in vivo murine data. While adenovirus-infecte d human DCs could prime an antiviral CTL response after several rounds of in vitro stimulation (Butterfield et al., 1998; Perez-Diez et al., 1998), mice immunized with adenovirus-infect ed DCs did not develop significant antiviral CTLs (Brossart et al., 1997; Kaplan et al., 1999). Furtherm ore, adenoviral immune mice could still be protected from tumor challenge by immunization with DCs infected by adenovirus encoding TAA transgenes (Kaplan et al., 1999). A paucity of antiadenoviral immunity after immunization with adeno-infected DCs has also been reported by Wan et al. (1997). While these results raise concerns that mice may not represent a suitable model for studying in vivo effects of adenovirus-infecte d DCs (possibly because of a reduced ability to mount an antiviral response compared with humans), these disparate results may also represent differences arising from the priming of CTLs in vitro versus in vivo. Collectively, it appears that adenovirus (and possibly other viral vectors) represents an efficient means for inserting transgenes into DCs without detrimental effects to its phenotype or function.

\section{Tumor antigen gene-modified DCs capable of priming antitumor immunity}

The feasibility of gene modification of DCs to express TAA was first reported by Alijagic et al. (1995). Using peripheral blood monocytes cultured in GM-CSF and IL-4, these investigators were able to transfect the resulting DCs with either a chloramphenicol acetyl transferase (CAT) reporter gene or a gene encoding human tyrosinase, a melanoma TAA. Gene transfection (via cationic lipids) resulted in a fivefold increase in CAT activity, while tyrosinase-transfe cted DCs elicited T cell clustering and TNF- $\alpha$ release in an antigen-specific CTL clone similar to that achieved using peptide-pulsed DCs (Alijagic et al., 1995). However, neither transfection efficiency nor the effect of transfection on DC phenotype and function (other than activation of a long-term $\mathrm{T}$ cell clone) was determined.

Another approach to engineering DCs to express TAA was demonstrated by Reeves et al. (1996), who utilized retroviral transduction to deliver the MART-1 melanoma TAA. Since retrovirus most efficiently introduces genes into actively cycling cells, CD $34^{+}$hematopoietic stem progenitor cells (HSCs) as cycling DC precursors were chosen as targets. Using murine CD86 as a marker for viral transfection, 20\% transfection efficiency, as determined by flow cytometric analysis of murine CD86-expressing cells, resulted from infection of HSCs. MART-1-expressing DCs were able to stimulate MART-1specific tumor-infiltrating lymphocytes (TILs) in vitro. These DCs could generate a MART-1-specific CTL response from autologous peripheral blood mononuclear cells (PBMCs), suggesting that like protein or peptide-pulsed DCs, genetically modified DCs could initiate a specific antitumor T cell response.

In an attempt to improve the efficiency of transgeneexpressing DCs, pox and adenoviral vectors capable of directly infecting DCs have been used to express TAA. Infection with either a fowlpox or vaccinia viral vector encoding MART-1 resulted in 50-75\% MART-1-expressing DCs (Kim et al., 1997). A single stimulation of peripheral blood lymphocytes (PBLs) from some melanoma patients with MART-1 transgeneexpressing DCs but not with MART-1 peptide-pulsed DCs resulted in antigen-specific IFN- $\gamma$ production and CTL generation. Full processing of the whole MART-1 protein and presentation by the DCs was confirmed by generation of CTLs against multiple MART-1 epitopes. Other investigators using an adenoviral vector encoding full-length MART-1 also reported the generation of MART-1-specific CTLs by virally infected DCs (Butterfield et al., 1998; Perez-Diez et al., 1998). MART-1-expressing DCs (but not DCs infected with empty vector) stimulated IFN- $\gamma$ production by $\mathrm{CD}^{+}$and $\mathrm{CD}^{+}{ }^{+} \mathrm{T}$ cells from many melanoma patients and healthy donors as measured by bulk enzyme-linked immunosorbent assay (ELISA) and intracellular cytokine staining (Perez-Diez et al., 1998). Interestingly, no IL-4-producing $\mathrm{T}$ cells arose from coculture of 
MART-1-expressing DCs with bulk PBLs, suggesting a bias towards generation of a helper $\mathrm{T}$ cell type 1 (Th1) response by TAA gene-modified DCs (Perez-Diez et al., 1998). TAAspecific CTLs or IFN- $\gamma$ production could not be elicited by virally infected DC-stimulated peripheral blood in all melanoma patients. Also of note, adenovirus-specif ic CTLs and IFN- $\gamma$ production were present in PBL cultures after repeated stimulation with adeno-infected DCs, raising a concern about the efficacy of virally infected DCs in vivo (see above) (Butterfield et al., 1998; Perez-Diez et al., 1998). With those caveats in mind, however, these data suggest that DCs expressing a full-length TAA protein were capable of processing and presenting TAA via both the MHC class I and class II pathways and could elicit superior $\mathrm{T}$ cell stimulation compared with peptide-pulsed DCs.

Mouse tumor models have been used to test the in vivo therapeutic efficacy of TAA gene-modified DCs. Early efforts centered on tumor lines altered to express a model "tumor" antigen such as $\beta$-galactosidase ( $\beta$-Gal) or ovalbumin (OVA) and DCs expressing $\beta$-Gal or OVA transgenes (Brossart et al., 1997; Song et al., 1997; Specht et al., 1997; Wan et al., 1997; McArthur and Mulligan, 1998; De Veerman et al., 1999). Both retroviral (Specht et al., 1997; De Veerman et al., 1999) and adenoviral (Brossart et al., 1997; Song et al., 1997; W an et al., 1997; McArthur and Mulligan, 1998) transduction systems have been used to insert genes encoding OVA or $\beta$-Gal into DCs derived from bone marrow or splenic precursors or immortalized DC lines. The resulting DCs generally showed no alterations in phenotype as measured by flow cytometric analysis of $\mathrm{T}$ cell stimulatory molecules such as MHC I/II, CD80/CD86, and ICAM-1 (De Veerman et al., 1999). Genetically modified DCs were able to activate antigen-specific $\mathrm{T}$ cell lines in vitro (Brossart et al., 1997; De Veerman et al., 1999), generate CTLs in vivo (Brossart et al., 1997; Song et al., 1997; Specht et al., 1997; Wan et al., 1997), and promote antitum or immunity in both naive and tumor-bearing mice (Brossart et al., 1997; Song et al., 1997; Specht et al., 1997; Wan et al., 1997; De Veerman et al., 1999). In some studies peptide-pulsed and genemodified DCs were compared for their ability to initiate T cell activation (both in vitro and in vivo) and antitumor immunity (Brossart et al., 1997; Specht et al., 1997). DCs infected with either an adenovirus or vaccinia virus encoding a CTL epitope of OVA were equivalent to OVA protein or peptide-pulsed DCs in their ability to activate an OVA-specific $\mathrm{CD}^{+} \mathrm{T}$ cell line, prime OVA-specific CTLs from naive mice, and generate CTLs on immunization in naive mice (Brossart et al., 1997). More importantly, virally (either adenovirus or vaccinia) transduced DCs generated protective antitumor immunity in both naive mice or mice previously infected with the corresponding virus, suggesting that antiviral immunity does not affect the efficacy of transfected DCs, at least in mice. Using DCs generated from retrovirally transduced bone marrow precursors, Specht et al. (1997) showed that genetically engineered DCs could promote therapeutic antitumor immunity in a metastatic model of disease. Treatment of day 3 lung metastases of a $\beta$-Gal-expressing CT26 colon carcinoma cell line was equally effective in reducing tumor load using either peptide-pulsed or genetransduced DCs; however, gene-transduced DCs were more potent primers of $\beta$-Gal CTLs in vivo. In another interesting mouse model, NFSA murine fibrosarcoma cells engineered to express the MART-1 human melanoma antigen were rejected in mice immunized with DCs transfected with a MART-1 gene-encoding adenovirus (Ribas et al., 1997). While these results are suggestive, tumor cells expressing novel antigens are rendered more immunogenic compared with the parental cell line, which poses the question of whether these results are due not to potent antigen presentation by DCs but rather arise from the artificial nature of the tumor model per se.

To that end, studies have addressed the question of whether DCs genetically engineered to express naturally occurring TAA are capable of eliciting antitumor immunity in vivo. Tuting et al. (1997) inserted a plasmid encoding wild-type p53 peptide into bone marrow-derived DCs via a particle bombardment or "gene gun" technique. This biolistic approach yielded a 5-10\% transfection efficiency and transgene expression lasting less than $72 \mathrm{hr}$ (Tuting et al., 1997). Nevertheless, immunization of naive mice with p53-transfected DCs resulted in protective immunity from a CMS4 sarcoma, which is known to overexpress p53 (Tuting et al., 1997). However, CMS4 is a chemically induced tumor, which is generally more immunogenic than naturally arising tumors found in humans. In another mouse model, immunization of naive mice with DCs transduced with an adenovirus encoding human p53 resulted in protection of $>70 \%$ of mice challenged with tumors expressing human p53 or those expressing mutated murine p53 (Ishida et al., 1999). Another report has shown that DCs infected with adenoviral vectors encoding different TAA expressed by the murine melanoma line B 16 could elicit antitumor immunity to this naturally occurring and poorly immunogenic tumor model (Kaplan et al., 1999). In this study, DCs infected by adenovirus showed a $95 \%$ transfection efficiency and no alterations in phenotype, with the exception of an increase in MHC class I expression. When expressed by DCs, target genes encoding CTL epitopes of tyrosinase-related protein 2 (TRP-2), or human gp100 (hgp100), but not mouse gp100, elicited nearly complete protective immunity in immunized mice subsequently challenged with viable tumor cells. Immunization with TRP-2- and hgp100-expressing DCs could also slow the growth of recently implanted tumors; combination of both TAA-expressing DCs further enhanced the antitumor effect. Although encouraging, established tumors could not be completely eliminated after vaccination with TAA-expressing DCs even though treatment began 4 days after tumor challenge, before a palpable tumor arises (Kaplan et al., 1999). This limitation may be due to the fact that only CTL epitopes were encoded by the transgene and that the DCs could not fully initiate $\mathrm{CD}^{+} \mathrm{T}$ cell activation in the absence of helper epitopes, a requisite for antitumor immunity (Toes et al., 1999). These translational studies extend the in vitro data using genetically modified human DCs to stimulate antitumor immunity to well-characterize $\mathrm{d}$ animal models. The results to date suggest that TAAs are suitable transgenes for use in immunotherapy protocols (Table 2). However, since most of these models utilize artificially generated tumor antigens or treated mice with small tum or loads (and did not result in curative treatment), further modification of the system will need to be carried out to improve therapeutic results.

\section{Cytokine gene-modified DCs}

Besides genetic modification to express TAA, DCs have been successfully gene modified to express immunomodulatory 
Table 2. Tumor Antigen Gene-Modified DCs

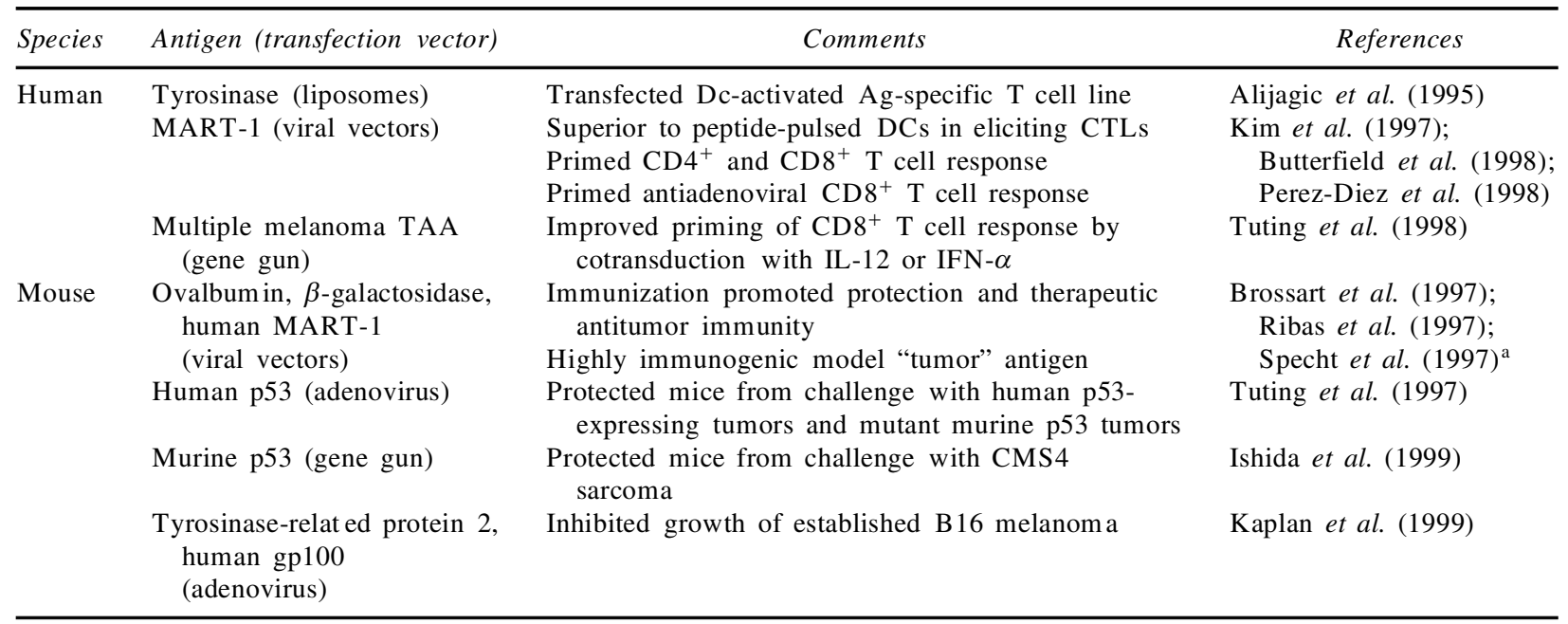

${ }^{\mathrm{a}} \mathrm{See}$ text for complete references.

proteins such as cytokines and chemokines (Table 3). One disadvantage in selecting TAA as a target gene for modification of DCs is the tissue and MHC haplotype restriction of whole tumor proteins and CTL epitopes, respectively. But DCs modified to express genes encoding $\mathrm{T}$ cell stimulatory cytokines, for example, may be potentially used as adjuvants to treat any number of tumors, so long as a source of TAA is available. Cytokine gene-modified DCs represent a potentially more potent vaccine than similarly gene-modified tumor cells since the former are both APC and cytokine factories while the latter require host APC function (Tepper and Mulé, 1994).

In murine models of melanoma and sarcoma, IL-12 genemodified DCs injected directly into tumors induced a profound antitumor response (Nishioka et al., 1999). While the amount of tumor growth inhibition correlated with IL-12 production by the DCs, the effect was dependent on DC stimulation of tumorspecific immunity because IL-12 gene-modified fibroblasts injected intratumorally had little effect on tumor growth (Nishioka et al., 1999). Tuting et al. (1998) reported that IL-12 gene-m odified DCs could boost priming of TAA-specific CD8 ${ }^{+}$ CTLs in vitro. In this study, DCs were genetically modified to express different melanoma TAAs as well as either IL-12 or IFN- $\alpha$. IL-12 gene modification has also been shown to boost $\mathrm{CD} 4^{+} \mathrm{T}$ cell responses in infectious disease models. CD $34^{+}$
DCs derived from peripheral blood and retrovirally transduced with genes to produce either IL-12 or IFN- $\gamma$ could augment $\mathrm{CD}^{+} \mathrm{T}$ cell-mediated cytokine production in response to bacterial antigens (Ahuja et al., 1998). Furthermore, immunization of naive mice with IL-12 gene-modified DCs loaded with soluble antigens from Leishmania donovani provided better protection from leishmaniasis than antigen-loaded unmodified DCs (Ahuja et al., 1999). In both the mouse and human studies, IL-12 gene transfer led to DC maturation, as measured by increased MHC class II and costimulatory molecule expression (Tuting et al., 1998; Nishioka et al., 1999). Together, IL-12 gene modification of DCs could augment priming to antigens delivered to DCs in a variety of manners and that these DC could represent powerful adjuvants for activation of both $\mathrm{CD} 4^{+}$ helper $\mathrm{T}$ cells and $\mathrm{CD} 8^{+} \mathrm{CTLs}$.

Additional cytokine genes have been introduced into DCs with the intent of increasing adjuvanticity. Retroviral infection of PBMCs with an IL-7 gene construct followed by maturation with GM-CSF plus IL-4 resulted in a DC population with increased stimulatory capacity compared with untransfected cells (Westermann et al., 1998). Presumably, the increased proliferation seen in allogeneic and autologous MLR was due to IL-7 enhancement of $\mathrm{T}$ cell proliferation. However, MLR assays do not address how cytokine expression of DCs affects antigen-

Table 3. Cytokine Gene-Modified Dendritic Cells

\begin{tabular}{|c|c|c|}
\hline Cytokine & Use of gene-modified DCs (species) & References \\
\hline GM-CSF & $\begin{array}{l}\text { Immunization for treatment of established tumors } \\
\text { (mice) }\end{array}$ & $\begin{array}{l}\text { Cao et al. (1999); Curiel-Lewandrowski } e \\
\text { (1999) }\end{array}$ \\
\hline Lymphotactin & $\begin{array}{l}\text { Immunization for treatment of established tumors } \\
\text { (mice) }\end{array}$ & Cao et al. (1999); Zhang et al. (1999) \\
\hline IL-12 & $\begin{array}{l}\text { In vitro priming of human } \mathrm{T} \text { cells } \\
\text { Intratumoral injection (mice) } \\
\text { Immunization against leishmaniasis (mice) }\end{array}$ & $\begin{array}{l}\text { Ahuja et al. (1998); Tuting et al. (1998) } \\
\text { Nishioka et al. (1999) } \\
\text { Ahuja et al. (1999) }\end{array}$ \\
\hline IL-7 & $\begin{array}{l}\text { In vitro stimulation of MLR in human PBLs } \\
\text { Intratumoral injection (mice) }\end{array}$ & $\begin{array}{l}\text { Westermann et al. (1998) } \\
\text { Miller et al. (2000) }\end{array}$ \\
\hline
\end{tabular}


Table 4. Comparisons of TAA Gene-Modified DCs with TAA Peptide-Pulsed DCs

\begin{tabular}{|c|c|c|c|}
\hline Source of DCs & Tumor antigen & Results & Reference \\
\hline $\begin{array}{l}\text { Adherent human PBMCs } \\
\text { cultured in GM-CSF + IL-4 }\end{array}$ & $\begin{array}{l}\text { MART-1: full-length } \\
\text { cDNA versus } \\
\text { MART- } 1_{27-35} \text { peptide }\end{array}$ & $\begin{array}{l}\text { Increased IFN- } \gamma \text { production } \\
\text { by CTLs raised } \\
\text { by gene-modified DCs }\end{array}$ & $\begin{array}{l}\text { Kim et al. } \\
\quad(1997)\end{array}$ \\
\hline $\begin{array}{l}\text { Murine bone marrow cells } \\
\text { cultured in GM-CSF + IL-4 }\end{array}$ & $\begin{array}{l}\beta \text {-Galactosidase: full-length } \\
\text { LacZ cDNA versus } \\
\beta \text {-Gal } \\
876-884 \text { peptide }\end{array}$ & $\begin{array}{l}\text { Equivalent protective tumor } \\
\text { immunity; superior } \\
\text { generation of IFN- } \gamma \text { and } \\
\text { CTLs in vitro } \\
\text { by gene-modified DCs }\end{array}$ & $\begin{array}{l}\text { Specht et al. } \\
\text { (1997) }\end{array}$ \\
\hline
\end{tabular}

specific or, more specifically, tumor antigen-specific $\mathrm{T}$ cell activation. Further experimentation using antigen-specific CTL assays and in vivo tests of therapeutic efficacy will be necessary in order to determine if IL-7 gene modification represents a significant improvement on DC-based vaccines. In this regard, one report suggests that IL-7 gene-modified DCs can mediate tumor regression through direct intratumoral injection (Miller et al., 2000). Two reports suggest that modification of DCs with another cytokine cDNA, GM-CSF, can increase therapeutic antitumor immunity in vivo as compared with unmodified DCs (Cao et al., 1999; Curiel-Lewandrowski et al., 1999). However, the level of increased antitumor immunity varied between the two studies. In a protective immunity model of a squamous cell carcinom a, $20 \%$ of mice immunized with lysatepulsed, GM-CSF gene-modified DCs (derived from GMCSF-cultured bone marrow cells) developed a tumor as opposed to $100 \%$ of mice treated with unmodified but lysate-pulsed DCs (Curiel-Lewandrowski et al., 1999). It was postulated that increased survival of and migration by GM-CSF gene-modified DCs were responsible for the increased antitumor immunity (Curiel-Lewandrowski et al., 1999). However, in the B16 mouse melanoma model, GM-CSF-expressing splenic DCs fused with tumor cells were only slightly (but not significantly) more effective than unmodified DC/tumor fusions in both protecting mice from tumor challenge and increasing survival of mice with established metastatic disease (Cao et al., 1999). It is unlikely that this discrepancy is due to reported differences in GM-CSF production as Cao et al. (1999) reported GM-CSF levels in DC supernatants three to five times the levels reported by Curiel-Lewandrowski et al. (1999). More likely, the difference resides in the tissue source of DCs because bone marrowderived DCs were shown previously to be more potent APCs than splenic DCs and have increased antigen-processing capacity (Fields et al., 1998). However, differences in tumor models and antigen loading may also explain these contradictory results, which may have potential significance for the design of clinical protocols. Finally, DCs genetically engineered to secrete a $\mathrm{T}$ cell chemotactic factor, lymphotactin, and subsequently loaded with a peptide of the Mut1 TAA were found to be potent stimulators of antitumor immunity against the 3LL Lewis lung carcinoma (Cao et al., 1998). In this study, lymphotactin gene-modified DCs were significantly more potent than unmodified DCs. When tumor RNA was used as the source of antigen, lymphotactin-se creting DCs were also superior to untransfected DCs in the induction of antitumor immunity to the B16 melanoma (Zhang et al., 1999), suggesting that this chemokine could be applicable to a range of tumors and antigen sources. Because of the emerging evidence that chemokines play an important role in the priming of naive T cells by DCs (Cyster, 1999), it is likely that future reports will describe the modification of DCs with genes encoding other chemokines.

\section{CONCLUSION}

A number of studies have indicated that genetic modification of DCs can improve their immunostimulatory capacity and provide an efficient means for antigen delivery to T cells. Animal tumor model data suggest that tumor antigen- and cytokine gene-transfected DCs are equally capable and, in many cases, superior APCs relative to unmodified DCs. It is premature at this point to render a decision on whether TAA gene-modified DCs represent a significant improvement in the development of DC-based cancer vaccines since only four studies to date have directly compared the efficacy of TAA gene-transduced DCs with TAA peptide-pulsed counterparts (Table 4). The cumulative results of these studies provide inconclusive evidence to support the hypothesis that TAA gene-expressing DCs are superior APCs relative to TAA peptide-pulsed DCs. Furthermore, tumor lysate- or tumor RNA-pulsed DCs should be compared with TAA gene-modified DCs in order to determine if presentation of a single TAA (via transgene expression) can induce the same level of antitumor immunity as DCs expressing multiple TAAs. However, the results using cytokine gene-modified DCs show, with few exceptions, a significant enhancement of $\mathrm{T}$ cell priming and antitum or immunity. An important issue that must still be addressed centers on the multitude of tissue culture protocols employed and different cellular sources from 
which DC can be generated. Future work in this field should involve determining optimal conditions and maturation factors for gene-modified DCs. An early indication of this effort comes from a comparison of the timing of antigen pulsing and CD40 maturation in peptide and tumor RNA-loaded DCs (Morse et al., 1998). The effect of CD40-mediated DC maturation on $\mathrm{T}$ cell stimulation was found to be most effective when it occurred after peptide pulsing but before loading with tumor RNA. It remains to be seen what temporal restrictions apply to gene modification of DCs with regard to DC maturation protocols. Finally, the question of which target genes are ideally suited for the clinic remains to be fully addressed. Because cytokine production by DCs may enhance antitumor immunity against tumors, it is conceivable that genes encoding cytokines IL-7 and IL-12 or the chemokine lymphotactin may be the first to be used in experimental DC-based vaccines in humans. However, it is also likely that additional cytokines will be shown to augment DC priming of an antitumor response. Another, as yet untested, avenue of research into gene-modified DCs involves expression of $\mathrm{T}$ cell adhesion/costimulatory molecules such as B7 or ICAM-1 or DC survival receptors such as CD40 or TRANCE-R. Just as the initial discovery of DC-mediated antitumor immunity prompted excitement for future therapeutics, the early success of gene-modified DCs has engendered another round of optimism.

\section{NOTE ADDED IN PROOF}

Since the initial submission of this article, several reports have described the use of genetically modified DC. Using retrovirally transduced murine DC encoding full-length OVA protein or a class I MHC restricted epitope of OVA, Schnell et al. (2000) provide evidence for a role of $\mathrm{CD}^{+} \mathrm{T}$ cells in the generation of antitumor immunity against OVA-expressing tumors but not for the initial generation of OVA-specific CTL. Immunization of mice with DC genetically modified to express either full-length human gp100 (Wan et al., 1999) or human MART-1 (Ribas et al., 2000) can protect mice from a lethal challenge of B16 melanoma cells (Wan et al., 1999). MART1 gene-modified human DC were equivalent to protein loaded counterparts in their ability to stimulate MART-1 specific CTL from melanom a patients (Philip et al., 2000). However, Osterroth et al. (2000) report that idiotype protein-pulsed DCs were far superior to idiotype gene-modified DCs (via Semlike forest virus) in inducing antigen-specific CTL from PBMC. Finally, Jonuleit et al. (2000) report that infection of CD83 ${ }^{+}$human DC with adenoviral vectors leads to suppression of the allostimulatory capacity of DC.

\section{ACKNOWLEDGMENTS}

We thank Dr. Elaine Thomas and Kathleen Picha (Immunex Corporation) and Dr. Satwant Narula (Schering-Plough Corporation) for providing recombinant GM-CSF and IL-4, respectively. This work was supported by grants from the National Cancer Institute/ National Institutes of Health (1 R01 CA71669, 5 P01 CA59327, and M01-RR00042), from the Department of Defense/U.S. Army (DAMD17-96-1-6103 and DAAG55-97-1-
0239), and by a gift from C.J. and E.C. Aschauer and Abbot Laboratories.

\section{REFERENCES}

AHUJA, S.S., MUMMIDI, S., MALECH, H.L., and AHUJA, S.K. (1998). Human dendritic cell (DC)-based anti-infective therapy: Engineering DCs to secrete functional IFN-gamma and IL-12. J. Immunol. 161, 868-876.

AHUJA, S.S., REDDICK, R.L., SATO, N., MONTALBO, E., KOSTECKI, V., ZHAO, W., DOLAN, M.J., MELBY, P.C., and AHUJA, S.K. (1999). Dendritic cell (DC)-based anti-infective strategies: DCs engineered to secrete IL-12 are a potent vaccine in a murine model of an intracellular infection. J. Immunol. 163, 3890-3897.

AICHER, A., WESTERMANN, J., CAYEUX, S., WILLIMSKY, G., DAEMEN, K., BLANKENSTEIN, T., UCKERT, W., DORKEN, B., and PEZZUTTO, A. (1997). Successful retroviral mediated transduction of a reporter gene in human dendritic cells: Feasibility of therapy with gene-modified antigen presenting cells. Exp. Hematol. 25, 39-44.

ALIJAGIC, S., MOLLER, P., ARTUC, M., JURGOVSKY, K., CZARNETZKI, B.M., and SCHADENDORF (1995). Dendritic cells generated from peripheral blood transfected with human tyrosinase induce specific T cell activation. Eur. J. Immunol. 25, 3100-3107.

ARTHUR, J.F., BUTTERFIELD, L.H., ROTH, M.D., BUI, L.A., KIERTSCHER, S.M., LAU, R., DUBINETT, S., GLASPY, J., MCBRIDE, W.H., and ECONOMOU, J.S. (1997). A comparison of gene transfer methods in human dendritic cells. Cancer Gene Ther 4, 17-25.

BANCHEREAU, J., and STEINMAN, R.M. (1998). Dendritic cells and the control of immunity. Nature (London) 392, 245-252.

BENDER, A., SAPP, M., SCHULER, G., STEINMAN, R.M., and BHARDWAJ, N. (1996). Improved methods for the generation of dendritic cells from nonproliferating progenitors in human blood. $\underline{\mathrm{J}}$. Immunol. Methods 196, 121-135.

BERGELSON, J.M., CUNNINGHAM, J.A., DROGUETT, G., KURTJONES, E.A., KRITHIVAS, A., HONG, J.S., HORWITZ, M.S., CROWELL, R.L., and FINBERG, R.W. (1997). Isolation of a common receptor for coxsackie B viruses and adenoviruses 2 and 5. Science 275, 1320-1323.

BERGELSON, J.M., KRITHIVAS, A., CELI, L., DROGUETT, G., HORWITZ, M.S., WICKHAM, T., CROWELL, R.L., and FINBERG, R.W. (1998). The murine CAR homolog is a receptor for coxsackie B viruses and adenoviruses. J. Virol. 72, 415-419.

BROSSART, P., GOLDRATH, A.W., BUTZ, E.A., MARTIN, S., and BEVAN, M.J. (1997). Virus-mediated delivery of antigenic epitopes into dendritic cells as a means to induce CTL. J. Immunol. 158, 3270-3276.

BROWN, M., DAVIES, D.H., SKINNER, M.A., BOWEN, G., HOLLINGSWORTH, S.J., MUFTI, G.J., ARRAND, J.R., and STACEY, S.N. (1999). Antigen gene transfer to cultured human dendritic cells using recombinant avipoxvirus vectors. Cancer Gene Ther. 6, 238-245.

BUTTERFIELD, L.H., JILANI, S.M., CHAKRABORTY, N.G., BUI, L.A., RIBAS, A., DISSETTE, V.B., LAU, R., GAMRADT, S.C., GLASPY, J.A., MCBRIDE, W.H., MUKHERJI, B., and ECONOMOU, J.S. (1998). Generation of melanoma-specific cytotoxic T lymphocytes by dendritic cells transduced with a MART-1 adenovirus. J. Immunol. 161, 5607-5613.

CAO, X., ZHANG, W., HE, L., XIE, Z., MA, S., TAO, Q., YU, Y., HAMADA, H., and WANG, J. (1998). Lymphotactin gene-modified bone marrow dendritic cells act as more potent adjuvants for peptide delivery to induce specific antitumor immunity. J. Immunol. 161, $6238-6244$. 
CAO, X., ZHANG, W., WANG, J., ZHANG, M., HUANG, X., HAMADA, H., and CHEN, W. (1999). Therapy of established tumour with a hybrid cellular vaccine generated by using granulocytemacrophage colony-stimulating factor genetically modified dendritic cells. Immunology 97, 616-625.

COFFIN, R.S., THOMAS, S.K., THOMAS, N.S., LILLEY, C.E., PIZZEY, A.R., GRIFFITHS, C.H., GIBB, B.J., WAGSTAFF, M.J., INGES, S.J., BINKS, M.H., CHAIN, B.M., THRASHER, A.J., RUTAULT, K., and LATCHMAN, D.S. (1998). Pure populations of transduced primary human cells can be produced using GFP expressing herpes virus vectors and flow cytometry. Gene Ther. 5, 718-722.

COHEN, P.J., COHEN, P.A., ROSENBERG, S.A., KATZ, S.I., and MULÉ, J.J. (1994). Murine epidermal Langerhans cells and splenic dendritic cells present tumor-associated antigens to primed $\mathrm{T}$ cells. Eur. J. Immunol. 24, 315-319.

CURIEL-LEW ANDROWSKI, C., MAHNKE, K., LABEUR, M., ROTERS, B., SCHMIDT, W., GRANSTEIN, R.D., LUGER, T.A., SCHWARZ, T., and GRABBE, S. (1999). Transfection of immature murine bone marrow-derived dendritic cells with the granulocytemacrophage colony-stimulating factor gene potently enhances their in vivo antigen-presenting capacity. J. Immunol. 163, 174-183.

CYSTER, J.G. (1999). Chemokines and the homing of dendritic cells to the $\mathrm{T}$ cell areas of lymphoid organs. J. Exp. Med. 189, 447-450.

DE VEERMAN, M., HEIRMAN, C., VAN, M.S., DEVOS, S., CORTHALS, J., MOSER, M., and THIELEMANS, K. (1999). Retrovirally transduced bone marrow-derived dendritic cells require $\mathrm{CD} 4+\mathrm{T}$ cell help to elicit protective and therapeutic antitumor immunity. J. Immunol. 162, 144-151.

DIEBOLD, S.S., KURSA, M., WAGNER, E., COTTEN, M., and ZENKE, M. (1999a). Mannose polyethylenimine conjugates for targeted DNA delivery into dendritic cells. J. Biol. Chem. 274, 19087-19094.

DIEBOLD, S.S., LEHRMANN, H., KURSA, M., WAGNER, E., COTTEN, M., and ZENKE, M. (1999b). Efficient gene delivery into human dendritic cells by adenovirus polyethylenimine and mannose polyethylenimine transfection. Hum. Gene Ther. 10, 775-786.

DIETZ, A.B., and VUK-PAVLOVIC, S. (1998). High efficiency adenovirus-mediated gene transfer to human dendritic cells. Blood $\mathbf{9 1}$, 392-398.

FIELDS, R.C., OSTERHOLZER, J.J., FULLER, J.A., THOMAS, E.K., GERAGHTY, P.J., and MULÉ, J.J. (1998). Comparative analysis of murine dendritic cells derived from spleen and bone marrow. J. Immunother. 21, 323-339.

HART, D.N. (1997). Dendritic cells: Unique leukocyte populations which control the primary immune response. Blood 90, 3245-3287.

HSU, F.J., BENIKE, C., FAGNONI, F., LILES, T.M., CZERW INSKI, D., TAIDI, B., ENGLEMAN, E.G., and LEVY, R. (1996). Vaccination of patients with B-cell lymphoma using autologous antigenpulsed dendritic cells. Nature Med. 2, 52-58.

ISHIDA, T., CHADA, S., STIPANOV, M., NADAF, S., CIERNIK, F.I., GABRILOVICH, D.I., and CARBONE, D.P. (1999). Dendritic cells transduced with wild-type p53 gene elicit potent anti-tumour immune responses. Clin. Exp. Immunol. 117, 244-251.

JONULEIT, H., TUTING, T., STEITZ, J., BRUCK, J., GIESECKE, A., STEINBRINK, K., KNOP, J., and ENK, A.H. (2000). Efficient transduction of mature $\mathrm{CD} 83^{+}$dendritic cells using recombinant adenovirus suppressed T cell stimulatory capacity. Gene Ther. 7, 249.

KAPLAN, J.M., YU, Q., PIRAINO, S.T., PENNINGTON, S.E., SHANKARA, S., WOODWORTH, L.A., and ROBERTS, B.L. (1999). Induction of antitumor immunity with dendritic cells transduced with adenovirus vector-encoding endogenous tumorassociated antigens. J. Immunol. 163, 699-707.

KIM, C.J., PREVETTE, T., CORMIER, J., OVERWIJK, W., RODEN, M., RESTIFO, N.P., ROSENBERG, S.A., and MARINCOLA, F.M. (1997). Dendritic cells infected with poxviruses encoding
MART-1/Melan A sensitize T lymphocytes in vitro. J. Immunother. 20, 276-286.

KUNIYOSHI, J.S., KUNIYOSHI, C.J., LIM, A.M., WANG, F.Y., BADE, E.R., LAU, R., THOMAS, E.K., and WEBER, J.S. (1999). Dendritic cell secretion of IL-15 is induced by recombinant huCD40LT and augments the stimulation of antigen-specific cytolytic T cells. Cell. Immunol. 193, 48-58.

LABEUR, M.S., ROTERS, B., PERS, B., MEHLING, A., LUGER, T.A., SCHWARZ, T., and GRABBE, S. (1999). Generation of tumor immunity by bone marrow-derived dendritic cells correlates with dendritic cell maturation stage. J. Immunol. 162, 168-175.

LUFT, T., PANG, K.C., THOMAS, E., HERTZOG, P., HART, D.N., TRAPANI, J., and CEBON, J. (1998). Type I IFNs enhance the terminal differentiation of dendritic cells. J. Immunol. 161, 1947-1953.

McARTHUR, J.G., and MULLIGAN, R.C. (1998). Induction of protective anti-tumor immunity by gene-modified dendritic cells. J. Immunother. 21, 41-47.

MILLER, P.W., SHARMA, S., STOLINA, M., BUTTERFIELD, L.H., LUO, J., LIN, Y., DOHADWALA, M., BATRA, R.K., WU, L., ECONOMOU, J.S., and DUBINETT, S.M. (2000). Intratumoral administration of adenoviral interleukin-7 gene-modified dendritic cells augments specific antitumor immunity and achieves tumor eradication. Hum. Gene Ther. 11, 53-65.

MORSE, M.A., LYERLY, H.K., GILBOA, E., THOMAS, E., and NAIR, S.K. (1998). Optimization of the sequence of antigen loading and CD40-ligand-in duced maturation of dendritic cells. Cancer Res. 58, 2965-2968.

MULDERS, P., PANG, S., DANNULL, J., KABOO, R., HINKEL, A., MICHEL, T., TSO, C.L., ROTH, M., and BELLDEGRUN, A. (1998). Highly efficient and consistent gene transfer into dendritic cells utilizing a combination of ultraviolet-irra diated adenovirus and poly(L-lysine) conjugates. Cancer Res. 58, 956-961.

NESTLE, F.O., ALIJAGIC, S., GILLIET, M., SUN, Y., GRABBE, S., DUMMER, R., BURG, G., and SCHADENDORF, D. (1998). Vaccination of melanoma patients with peptide- or tumor lysate-pulsed dendritic cells. Nature Med. 4, 328-332.

NISHIOKA, Y., HIRAO, M., ROBBINS, P.D., LOTZE, M.T., and TAHARA, H. (1999). Induction of systemic and therapeutic antitumor immunity using intratumoral injection of dendritic cells genetically modified to express interleukin 12. Cancer Res. 59, 4035-4041.

OSTERROTH, F., GARBE, A., FISCH, P., and VEELKEN, H. (2000). Stimulation of cytotoxic $\mathrm{T}$ cells against idiotype immunoglobulin of malignant lymphoma with protein-pulsed or idiotype-transduced dendritic cells. Blood 95, 1342

PEREZ-DIEZ, A., BUTTERFIELD, L.H., LI, L., CHAKRABORTY, N.G., ECONOMOU, J.S., and MUKHERJI, B. (1998). Generation of CD8+ and CD4+ T-cell response to dendritic cells genetically engineered to express the MART-1/Melan-A gene. $\underline{\text { Cancer Res. 58, }}$ 5305-5309.

PHILIP, R., ALTERS, S.E., BRUNETTE, E., ASHTON, J., GADEA, J., YAU, J., LEBKOWSKI, J., and PHILIP, M. (2000). Dendritic cells loaded with MART-1 peptide or infected with adenoviral construct are functionally equivalent in the induction of tumor-specific cytotoxic $\mathrm{T}$ lymphocyte responses in patients with melanoma. J. Immunother. 23, 168.

REA, D., SCHAGEN, F.H., HOEBEN, R.C., MEHTALI, M., HAVENGA, M.J., TOES, R.E., MELIEF, C.J., and OFFRINGA, R. (1999). Adenoviruses activate human dendritic cells without polarization toward a T-helper type 1-inducing subset. J. Virol. 73, 10245-10253.

REEVES, M.E., ROYAL, R.E., LAM, J.S., ROSENBERG, S.A., and HWO, P. (1996). Retroviral transduction of human dendritic cells with a tumor-associated antigen gene. Cancer Res. 56, 5672.

RIBAS, A., BUTTERFIELD, L.H., MCBRIDE, W.H., JILANI, S.M., BUI, L.A., VOLLMER, C.M., LAU, R., DISSETTE, V.B., HU, B., CHEN, A.Y., GLASPY, J.A., and ECONOMOU, J.S. (1997). Ge- 
netic immunization for the melanoma antigen MART-1/Melan-A using recombinant adenovirus-transduced murine dendritic cells. Cancer Res. 57, 2865-2869.

RIBAS, A., BUTTERFIELD, L.H., HU, B., DISSETTE, V.B., CHEN, A.Y., KOH, A., AMARNANI, S.N., GLASPY, J.A., McBRIDE, W.H., and ECONOMOU, J.S. (2000). Generation of T-cell immunity to a murine melanoma using MART-1-engineered dendritic cells. J. Immunother. 23, 59.

ROMANI, N., REIDER, D., HEUER, M., EBNER, S., KAMPGEN, E., EIBL, B., NIEDERWIESER, D., and SCHULER, G. (1996). Generation of mature dendritic cells from human blood. An improved method with special regard to clinical applicability. J. Immunol. Methods 196, 137-151.

SCHNELL, S., YOUNG, J.W., HOUGHTON, A.N., and SADELAIN, M. (2000). Retrovirally transduced mouse dendritic cells require $\mathrm{CD}^{+} \mathrm{T}$ cell help to elicit antitumor immunity: Implications for the clinical use of dendritic cells. J. Immunol. 164, 1243.

SCHULER, G., and STEINMAN, R.M. (1997). Dendritic cells as adjuvants for immune-mediated resistance to tumors. J. Exp. Med. 186, 1183-1187.

SONDERBYE, L., FENG, S., YACOUBIAN, S., BUEHLER, H., AHSAN, N., MULLIGAN, R., and LANGHOFF, E. (1998). In vivo and in vitro modulation of immune stimulatory capacity of primary dendritic cells by adenovirus-mediated gene transduction. Exp. Clin. Immunogenet. 15, 100-111.

SONG, W., KONG, H.L., CARPENTER, H., TORII, H., GRANSTEIN, R., RAFII, S., MOORE, M.A., and CRYSTAL, R.G. (1997). Dendritic cells genetically modified with an adenovirus vector encoding the cDNA for a model antigen induce protective and therapeutic antitumor immunity. J. Exp. Med. 186, 1247-1256.

SPECHT, J.M., WANG, G., DO, M.T., LAM, J.S., ROYAL, R.E., REEVES, M.E., ROSENBERG, S.A., and HWU, P. (1997). Dendritic cells retrovirally transduced with a model antigen gene are therapeutically effective against established pulmonary metastases. J. Exp. Med. 186, 1213-1221.

TALMOR, M., MIRZA, A., TURLEY, S., MELLMAN, I., HOFFMAN, L.A., and STEINMAN, R.M. (1998). Generation or large numbers of immature and mature dendritic cells from rat bone marrow cultures. Eur. J. Immunol. 28, 811-817.

TEPPER, R.I., and MULÉ, J.J. (1994). Experimental and clinical studies of cytokine gene-modified tumor cells. Hum. Gene Ther. 5, 153-164.

TILLMAN, B.W., DE GRUIJL, T.D., LUYKX-DE BAKKER, S.A., SCHEPER, R.J., PINEDO, H.M., CURIEL, T.J., GERRITSEN, W.R., and CURIEL, D.T. (1999). Maturation of dendritic cells accompanies high-efficiency gene transfer by a CD40-targeted adenoviral vector. J. Immunol. 162, 6378-6383.

TIMMERMAN, J.M., and LEVY, R. (1999). Dendritic cell vaccines for cancer immunotherapy. Annu. Rev. Med. 50, 507-529.

TOES, R.E., OSSENDORP, F., OFFRINGA, R., and MELIEF, C.J. (1999). CD4 T cells and their role in antitumor immune responses. J. Exp. Med. 189, 753-756. [Comment].

TUTING, T., DeLEO, A.B., LOTZE, M.T., and STORKUS, W.J. (1997). Genetically modified bone marrow-derived dendritic cells expressing tumor-associated viral or "self" antigens induce antitumor immunity in vivo. Eur. J. Immunol. 27, 2702-2707.

TUTING, T., WILSON, C.C., MARTIN, D.M., KASAMON, Y.L.,
ROWLES, J., MA, D.I., SLINGLUFF, C.L., JR., WAGNER, S.N., VAN DER BRUGGER, B.P., BAAR, J., LOTZE, M.T., and STORKUS, W.J. (1998). Autologous human monocyte-derived dendritic cells genetically modified to express melanoma antigens elicit primary cytotoxic $\mathrm{T}$ cell responses in vitro: Enhancement by cotransfection of genes encoding the Th1-biasing cytokines IL-12 and IFN- $\alpha$. J. Immunol. 160, 1139-1147.

VAN TENDELOO, V.F., SNOECK, H.W., LARDON, F., VANHAM, G.L., NIJS, G., LENJOU, M., HENDRIKS, L., VAN BROECKHOVEN, C., MOULIHN, A., RODRIGUS, I., VERDONK, P., VAN BOCKSTAELE, D.R., and BERNEMAN, Z.N. (1998). Nonviral transfection of distinct types of human dendritic cells: Highefficiency gene transfer by electroporation into hematopoietic progenitor-but not monocyte-derived dendritic cells. Gene Ther. 5, 700-707.

WAN, Y., EMTAGE, P., ZHU, Q., FOLEY, R., PILON, A., ROBERTS, B., and GAULDIE, J. (1999). Enhanced immune response to the melanoma antigen gp100 using recombinant adenovirus-transduced dendritic cells. Cell. Immunol. 198, 131.

WAN, Y., BRAMSON, J., CARTER, R., GRAHAM, F., and GAULDIE, J. (1997). Dendritic cells transduced with an adenoviral vector encoding a model tumor-associated antigen for tumor vaccination. Hum. Gene Ther. 8, 1355-1363.

WESTERMANN, J., AICHER, A., QIN, Z., CAYEUX, Z., DAEMEN, K., BlANKENSTEIN, T., DORKEN, B., and PEZZUTto, A. (1998). Retroviral interleukin-7 gene transfer into human dendritic cells enhances T cell activation. Gene Ther. 5, 264-271.

WICKHAM, T.J., MATHIAS, P., CHERESH, D.A., and NEMEROW, G.R. (1993). Integrins alpha $v$ beta 3 and alpha $v$ beta 5 promote adenovirus internalization but not virus attachment. Cell 73, 309-319.

WONG, B.R., JOSIEN, R., LEE, S.Y., SAUTER, B., LI, H.L., STEINMAN, R.M., and CHOI, Y. (1997). TRANCE (tumor necrosis factor $[\mathrm{TNF}]$-related activation-induced cytokine), a new TNF family member predominantly expressed in $\mathrm{T}$ cells, is a dendritic cellspecific survival factor. J. Exp. Med. 186, 2075-2080.

ZHANG, W., HE, L., YUAN, Z., XIE, Z., WANG, J., HAMADA, H., and CAO, X. (1999). Enhanced therapeutic efficacy of tumor RNApulsed dendritic cells after genetic modification with lymphotactin. Hum. Gene Ther. 10, 1151-1161.

ZHONG, L., GRANELLI-PIPERNO, A., CHOI, Y., and STEINMAN, R.M. (1999). Recombinant adenovirus is an efficient and nonperturbing genetic vector for human dendritic cells. Eur. J. Immunol. 29, 964-972.

Address reprint requests to: Dr. Christopher J. Kirk Department of Surgery University of Michigan Medical Center 1520 MSRB I

1150 West Medical Center Drive Ann Arbor, MI 48109-0666

E-mail: ckirk@umich.edu

Received for publication January 6, 2000; accepted after revision February 2, 2000. 


\section{This article has been cited by:}

1. Lili Yang, Haiguang Yang, Kendra Rideout, Taehoon Cho, Kye il Joo, Leslie Ziegler, Abigail Elliot, Anthony Walls, Dongzi Yu, David Baltimore, Pin Wang. 2008. Engineered lentivector targeting of dendritic cells for in vivo immunization. Nature Biotechnology 26:3, 326-334. [CrossRef]

2. Jin-Hai Gu, Gang Li. 2008. Dendritic cell-based immunotherapy for malignant glioma. Neuroscience Bulletin 24:1, 39-44. [CrossRef]

3. S. Justesen, S. Buus, M. H. Claesson, A. E. Pedersen. 2007. Addition of TAT protein transduction domain and GrpE to human $\mathrm{p} 53$ provides soluble fusion proteins that can be transduced into dendritic cells and elicit p53-specific T-cell responses in HLA-A*0201 transgenic mice. Immunology 122:3, 326-334. [CrossRef]

4. Dajing Xia, Terence Moyana, Jim Xiang. 2006. Combinational adenovirus-mediated gene therapy and dendritic cell vaccine in combating well-established tumors. Cell Research 16:3, 241-259. [CrossRef]

5. EBM van Leeuwen, S Cloosen, BLMG Senden-Gijsbers, WTV Germeraad, GMJ Bos. 2006. Transduction with a fiber-modified adenoviral vector is superior to non-viral nucleofection for expressing tumor-associated Ag mucin-1 in human DC. Cytotherapy 8:1, 36-46. [CrossRef]

6. A. Farkas, C. Conrad, G. Tonel, Z. Borbenyi, L. Kemeny, A. Dobozy, F.O. Nestle. 2006. Current State and Perspectives of Dendritic Cell Vaccination in Cancer Immunotherapy. Skin Pharmacology and Physiology 19:3, 124-131. [CrossRef]

7. Wilson S Meng, Lisa H Butterfield. 2005. Activation of antigen-presenting cells by DNA delivery vectors. Expert Opinion on Biological Therapy 5:8, 1019-1028. [CrossRef]

8. Jianping Pan, Minghui Zhang, Jianli Wang, Qingqing Wang, Dajing Xia, Wenji Sun, Lihuang Zhang, Hai Yu, Xuetao Cao. 2005. Intratumoral injection of interferon-gamma gene-modified dendritic cells elicits potent antitumor effects: effective induction of tumor-specific CD8+ CTL response. Journal of Cancer Research and Clinical Oncology 131:7, 468-478. [CrossRef]

9. Myrto Trakatelli, Michel Toungouz, Micheline Lambermont, Michel Heenen, Thierry Velu, Catherine Bruyns. 2005. Immune characterization of clinical grade-dendritic cells generated from cancer patients and genetically modified by an ALVAC vector carrying MAGE minigenes. Cancer Gene Therapy 12:6, 552-559. [CrossRef]

10. A Michiels, S Tuyaerts, A Bonehill, J Corthals, K Breckpot, C Heirman, S Van Meirvenne, M Dullaers, $\mathrm{S}$ Allard, F Brasseur, $\mathrm{P}$ van der Bruggen, $\mathrm{K}$ Thielemans. 2005. Electroporation of immature and mature dendritic cells: implications for dendritic cell-based vaccines. Gene Therapy 12:9, 772-782. [CrossRef]

11. Julianna Lisziewicz, Jeffrey Trocio, Lucia Whitman, Georg Varga, Jianqing Xu, Nyasha Bakare, Patrick Erbacher, Cecil Fox, Ruth Woodward, Phil Markham, Suresh Arya, Jean-Paul Behr, Franco Lori. 2005. DermaVir: A Novel Topical Vaccine for HIV/AIDS. Journal of Investigative Dermatology 124:1, 160-169. [CrossRef]

12. Karine Breckpot, Jurgen Corthals, Carlo Heirman, Aude Bonehill , Annelies Michiels , Sandra Tuyaerts, Catherine De Greef, Kris Thielemans . 2004. Activation of Monocytes via the CD14 Receptor Leads to the Enhanced Lentiviral Transduction of Immature Dendritic CellsActivation of Monocytes via the CD14 Receptor Leads to the Enhanced Lentiviral Transduction of Immature Dendritic Cells. Human Gene Therapy 15:6, 562-573. [Abstract] [PDF] [PDF Plus]

13. Lana Schumacher, Antoni Ribas, Vivian B. Dissette, William H. McBride, Bijay Mukherji, James S. Economou, Lisa H. Butterfield. 2004. Human Dendritic Cell Maturation by Adenovirus Transduction Enhances Tumor Antigen-Specific T-Cell Responses. Journal of Immunotherapy 27:3, 191-200. [CrossRef] 
14. P. PONSAERTS, V. F. I. VAN TENDELOO, Z. N. BERNEMAN. 2004. Cancer immunotherapy using RNA-loaded dendritic cells. Clinical and Experimental Immunology 134:3, 378-384. [CrossRef]

15. Sherven Sharma, Raj K. Batra, Seok Chul Yang, Sven Hillinger, Li Zhu, Kimberly Atianzar, Robert M. Strieter , Karen Riedl, Min Huang, Steven M. Dubinett . 2003. Interleukin-7 Gene-Modified Dendritic Cells Reduce Pulmonary Tumor Burden in Spontaneous Murine Bronchoalveolar Cell CarcinomaInterleukin-7 Gene-Modified Dendritic Cells Reduce Pulmonary Tumor Burden in Spontaneous Murine Bronchoalveolar Cell Carcinoma. Human Gene Therapy 14:16, 1511-1524. [Abstract] [PDF] [PDF Plus]

16. Richard C. Koya, Nori Kasahara, Patricia M. B. Favaro, Roy Lau, Huy Q. Ta, Jeffrey S. Weber, Renata Stripecke. 2003. Potent Maturation of Monocyte-Derived Dendritic Cells After CD40L Lentiviral Gene Delivery. Journal of Immunotherapy 26:5, 451-460. [CrossRef]

17. R.B. Batchu , A.M. Moreno , S. Szmania , S.K. Gupta , F. Zhan, N. Rosen , M. Kozlowski , T. Spencer , G.C. Spagnoli , J. Shaughnessy , B. Barlogie , G. Tricot, F. van Rhee . 2003. High-Level Expression of Cancer/Testis Antigen NY-ESO-1 and Human Granulocyte-Macrophage Colony-Stimulating Factor in Dendritic Cells with a Bicistronic Retroviral VectorHigh-Level Expression of Cancer/Testis Antigen NY-ESO-1 and Human Granulocyte-Macrophage Colony-Stimulating Factor in Dendritic Cells with a Bicistronic Retroviral Vector. Human Gene Therapy 14:14, 1333-1345. [Abstract] [PDF] [PDF Plus]

18. INGE MARIE SVANE, METTE LINE SOOT, SOREN BUUS, HANS E. JOHNSEN. 2003. Clinical application of dendritic cells in cancer vaccination therapy. APMIS 111:7-8, 818-834. [CrossRef]

19. Ian F. Parney, Lung-Ji Chang. 2003. Cancer immunogene therapy: A review. Journal of Biomedical Science 10:1, 37-43. [CrossRef]

20. Xueshu Zhang , John R. Gordon , Jim Xiang . 2002. Advances in Dendritic Cell-Based Vaccine of CancerAdvances in Dendritic Cell-Based Vaccine of Cancer. Cancer Biotherapy \& Radiopharmaceuticals 17:6, 601-619. [Abstract] [PDF] [PDF Plus]

21. Boris Kubuschok, Rudolf Schmits, Frank Hartmann, Christiane Cochlovius, Rainer Breit , Jochem König, Georg Pistorius, Martin Schilling, Christoph Renner, Michael Pfreundschuh . 2002. Use of Spontaneous Epstein-Barr Virus-Lymphoblastoid Cell Lines Genetically Modified to Express Tumor Antigen as Cancer Vaccines: Mutated p21 ras Oncogene in Pancreatic Carcinoma as a ModelUse of Spontaneous Epstein-Barr Virus-Lymphoblastoid Cell Lines Genetically Modified to Express Tumor Antigen as Cancer Vaccines: Mutated p21 ras Oncogene in Pancreatic Carcinoma as a Model. Human Gene Therapy 13:7, 815-827. [Abstract] [PDF] [PDF Plus]

22. G. Ramadan, R. E. Schmidt, J. Schubert. 2001. In vitro generation of human CD86+ dendritic cells from CD34+ haematopoietic progenitors by PMA and in serum-free medium. Clinical and Experimental Immunology 125:2, 237-244. [CrossRef]

23. Philip A Reay. 2001. Dendritic cells: immunological features and utilisation for tumour immunotherapy. Expert Opinion on Therapeutic Targets 5:4, 491-506. [CrossRef]

24. John Seigne, Scott Antonia, Mayer Fishman. 2001. Novel therapies for renal cell carcinoma. Expert Opinion on Investigational Drugs 10:6, 1033-1044. [CrossRef]

25. Naoki Nishimura , Yasuhiko Nishioka , Tsutomu Shinohara, Saburo Sone . 2001. Enhanced Efficiency by Centrifugal Manipulation of Adenovirus-Mediated Interleukin 12 Gene Transduction into Human Monocyte-Derived Dendritic CellsEnhanced Efficiency by Centrifugal Manipulation of Adenovirus-Mediated Interleukin 12 Gene Transduction into Human Monocyte-Derived Dendritic Cells. Human Gene Therapy 12:4, 333-346. [Abstract] [PDF] [PDF Plus]

26. Mack Barnes, Terri Pustilnik. 2001. Current Opinion in Obstetrics \& Gynecology 13:1, 47-51. [CrossRef] 
27. Siegfried Matzku, Margot Z??ller. 2001. Specific Immunotherapy of Cancer in Elderly Patients. Drugs \& Aging 18:9, 639-664. [CrossRef]

28. Andrew R Bateman, Kevin J Harrington, Alan A Melcher, Richard G Vile. 2001. Cancer gene therapy: developments to 2000. Expert Opinion on Investigational Drugs 9:12, 2799-2813. [CrossRef]

29. Yuri V. Bobryshev. 2000. Dendritic cells and their involvement in atherosclerosis. Current Opinion in Lipidology 11:5, 511-517. [CrossRef] 